\title{
HUBUNGAN PROGRAM CSR (CORPORATE SOCIAL RESPONSIBILITY) MUDIK LEBARAN GRATIS TERHADAP CITRA PERUSAHAAN PT. INDUSTRI JAMU DAN FARMASI SIDO MUNCUL TBK.
}

\author{
Dewi Eka Ningtyas \\ The London School Of Public Relations Jakarta \\ dewi_den@ymail.com
}

\begin{abstract}
The Business world is growing rapidly today with many companies competing to generate a huge profit yet leaving their social responsibility behind. Accordingly, a few companies engage in CSR (Corporate Social Responsibility) in order to increase the company's image to society's impression. This research aims to figure out whether there is a significant correlation of CSR (Corporate Social Responsibility) programme in the form of "Sido Muncul Mudik Lebaran Gratis" to the image of PT Industri Jamu dan Farmasi Sido Muncul Tbk. The first theories employed were CSR (Corporate Social Responsibility) theory and Corporate Image Theory. The research method used was Pearson's Correlation research method by using the quantitative analysis, in which questionnaires were spread to 100 herbalist traders in Pondok Gede area, East Jakarta. The scale in use was Semantic Differential with 10\% error rate.The research result shows that there is no correlation of CSR (Corporate Social Responsibility) programme in the form of "Sido Muncul Mudik Lebaran Gratis" to the image of PT Industri Jamu dan Farmasi Sido Muncul Tbk.
\end{abstract}

Keywords: CSR, Corporate Social Responsibility, Corporate Image.

\begin{abstract}
ABSTRAK
Saat ini dunia bisnis semakin berkembang, banyak perusahaan yang bersaing dalam mencari keuntungan dan melupakan tanggung jawab sosial. Maka dari itu, tidak sedikit perusahaan yang menggunakan CSR (Corporate Social Responsibility) untuk meningkatkan citra perusahaan di mata masyarakat. Penelitian ini bertujuan untuk mengetahui adakah hubungan program CSR (Corporate Social Responsibility) Mudik Lebaran Gratis terhadap citra PT Industri Jamu dan Farmasi Sido Muncul Tbk. Teori utama yang digunakan adalah teori CSR (Corporate Social Responsibility) dan teori Citra. Metode penelitian yang digunakan adalah metode penelitian Korelasi Pearson (Pearson's Correlation) dengan menggunakan analisis kuantitatif, menyebarkan kuesioner kepada 100 pedagang jamu di daerah Pondok Gede, Jakarta Timur. Skala yang digunakan adalah semantik diferensial dengan tingkat kesalahan 10\%. Hasil penelitian membuktikan bahwa tidak terdapat hubungan CSR (Corporate Social Responsibility) Mudik Lebaran Gratis terhadap Citra PT Industri Jamu dan Farmasi Sido Muncul Tbk.
\end{abstract}

Kata Kunci: CSR, Corporate Social Responsibility, Citra Perusahaan. 


\section{PENDAHULUAN}

Karena kesadaran masyarakat saat ini untuk menjaga kesehatan semakin tinggi. Banyaknya produk perusahaan jamu yang menawarkan varian produk yang sama, membuat persaingan semakin ketat dan menuntut sebuah perusahaan agar dapat lebih melakukan inovasi dalam melakukan usahanya. Perusahaan saat ini tidak hanya dituntut untuk mencari keuntungan atau laba, tetapi juga harus memperhatikan tanggung jawab sosial di masyarakat.

Dari segi ekonomi, perusahaan memang diharapkan mendapatkan keuntungan yang setinggi-tingginya. Sedangkan dari segi kepuasan pelanggan itu sudah menjadi tugas perusahaan untuk dapat memenuhi kebutuhan dan keinginan konsumen, sehingga perusahaan tidak hanya mencapai kepuasan konsumen, tetapi harus bisa mencapai loyalitas pelanggan. Sedangkan dalam aspek sosial, perusahaan harus memberikan kontribusi secara langsung kepada masyarakat yaitu dengan meningkatkan kualitas kehidupan masyarakat dan lingkungannya melalui program CSR atau tanggung jawab sosial.

Tanggung jawab sosial perusahaan bukan lagi hanya menjadi bentuk Filantropi dari perusahaan semata, namun saat ini tanggung jawab sosial sudah menjadi sebuah strategi dalam berbisnis.

Filantropi Islam yang meliputi zakat dan waqaf merupakan pranata yang potensial secara ekonomi. Filantropi Islam dalam sejarahnya telah berperan dalam penyebaran Islam, pendirian lembaga pendidikan, serta menyejahterakan masyarakat khususnya yang tidak mampu (Widyawati, 2011, p.186).

Philip L. Cochran (2006) menyatakan bahwa salah satu aspek perintis dalam tanggung jawab social perusahaan adalah filantropi perusahaan. Di era filantropi perusahaan modern, ketika korporasi mulai memberikan bantuan untuk tujuan dan manfaat tidak langsung perusahaan. Dalam dasawarsa berikutnya, standar filantropi perusahaan dengan memberikan sumbangan ke universitas, opera lokal, ata pada upaya peningkatan kesehatan masyarat dunia (dalam Mardikanto, 2014, p. 204). Menurut John M. Echols dan Hassan Shadly (dalam Nasrullah, 2015, p.4) secara estimologi, makna filantropi (philanthropy) adalah kedermawanan, kemurahatian, atau sumbangan sosial sesuatu yang menunjukkan cinta kepada manusia.

Sedangkan menurut Chaidier S. Bamualim dan Irfan Abubakar dalam Nasrullah (2015, p.5) istilah ini berasal dari bahasa Yunani yaitu philos (cinta) dan antrhopos (manusia), yang secara harafiah bermakna sebagai konseptualisasi dari praktek member (giving), pelayanan (service) dan asosiasi (association) dengan sukarela untuk membantu pihak lain yang membetuhkan sebagai apresiasi cinta. 
Friedman mengatakan bahwa Tanggung jawab sosial perusahaan adalah menjalankan bisnis sesuai dengan keingingan pemilik perusahaan (owners), biasanya dalam bentuk menghasilkan uang sebanyak mungkin dengan senantiasa mengindahkan aturan dasar yang digariskan dalam suatu masyarakat sebagaimana diatur oleh hukum dan perundang undangan (Solihin, 2009, p.6).

Menurut Post, (dalam Solihin, 2009, p.3) mengatakan bahwa sebuah perusahaan akan menjalankan tiga jenis tanggung jawab yang berbeda-beda di mana ketiga jenis tanggung jawab tersebut harus dijalankan secara seimbang. Ketiga jenis tanggung jawab tersebut mencakup:

\section{Economic Responsibility}

Perusahaan korporasi dibentuk dengan tujuan untuk menghasilkan laba secara optimal. Berkaitan dengan hal tersebut, para pengelola perusahaan korporasi memiliki tanggung jawab ekonomi di antaranya kepada para pemegang saham dalam bentuk dividen dan sebagian laba lainnya merupakan saldo laba/laba ditahan yang akan meningkatkan nilai dari suatu perusahaan.

2. Legal Responsibility

Perusahaan korporasi didirikan untuk menghasilkan laba, akan tetapi dalam melaksanakan operasinya perusahaan korporasi harus mematuhi berbagai peraturan perundang undangan yang berlaku sebagai bentuk tanggung jawab perusahaan.

3. Social Resposibility

Tanggung jawab ketiga yang harus dijalankan perusahaan adalah tanggung jawab sosial perusahaan.

Keinginan setiap manusia untuk memiliki tubuh yang menyehatkan ataupun cepat pulih dari sakit agar bisa kembali menjalankan kegiatannya itu sudah menjadi kewajiban setiap manusia untuk menjaga tubuhnya agar tetap sehat.

Salah satu cara yang digunakan oleh masyarakat Indonesia untuk tetap sehat dan bugar adalah dengan mengkonsumsi jamu tradisional. Perkembangan industri jamu di Indonesia sendiri baru dimulai sekitar tahun 1900-an dimana pabrik-pabrik jamu besar mulai berdiri di Indonesia seperti Jamu Jago, Mustika Ratu, Nyonya Meneer, Leo, Sido Muncul, Jamu Simona, Jamu Borobudur, Jamu Dami, Jamu Air Mancur, Jamu Pusaka Ambon, Jamu Bukit Mentjos, dan tenaga Tani Farma (Direktorat Kredit, BPR, dan UMKM, 2013,p.3).

Beragam pengobatan tradisional yang menggunakan bahan pokok dari tumbuhan berkhasiat obat sudah dikenal oleh masyarakat Indonesia sejak era ratusan tahun. Pengobatan cara tradisional ini disebut dengan jamu. Di antara tumbuhan berkhasiat yang digunakan dalam pengobatan herbal adalah mahkota dewa, sambilo, jahe merah, kunir putih, sambungnyawa, tapak dara, bawang putih, teh dan sebagainya. Bagianbagian tanaman dapat digunakan secara langsung, yakni untuk pengobatan luar dengan 
cara dioles atau dikompres. Sedangkan untuk pengobatan dalam dapat digunakan dengan cara dimakan atau diminum (Winasis, 2015.p.3).

Jamu tersedia dalam bentuk racikan atau ramuan siap pakai, misalnya jamu dan obat kemasan lain. Bahkan sudah banyak diproduksi obat herbal skala industri. Peningkatan penggunaan obat dari tanaman berkhasiat akhir-akhir ini menunjukkan bahwa pengobatan ini semakin dipercaya akan manfaatnya (Winasis, 2015, p.3).

Jamu tradisional merupakan sarana pengobatan tradisional yang mempunyai peranan yang sangat penting dalam pemerataan kesehatan masyarakat. Melihat hai tersebut diatas, jamu memiliki potensi yang sangat besar untuk dikembangkan sehingga ini menjadi peluang bagi pengrajin jamu untuk mengembangkan usahanya.

PT. Industri Jamu dan Farmasi Sido Muncul Tbk berdiri sejak tahun 1951. Perusahaan ini berfokus di dalam perindustrian jamu dan farmasi dengan menggunakan mesin-mesin mutakhir di pabriknya yang terletak di Semarang. Industri rumahan ini secara perlahan berkembang menjadi perusahaan besar dan terkenal seperti saat ini. Produk perseroan yang telah dikenal luas adalah Tolak Angin dan Kuku Bima (Sidomuncul).

Di tengah persaingan sektor Industri jamu yang semakin ketat, PT Industri Jamu dan Farmasi Sido Muncul Tbk telah berhasil memiliki market share tertinggi dan reputasi yang baik sebagai industri jamu terbesar di Indonesia. Keberhasilan yang telah dicapai saat ini tentunya tidak terlepas dari peran dan pelaku pendiri industri PT. Industri Jamu dan Farmasi Sido Muncul Tbk (Sidomuncul).

Saat ini PT. Industri Jamu dan Farmasi Sido Muncul Tbk telah melengkapi pabriknya dengan berbagai fasilitas pendukung yang memenuhi standar farmasi. Beberapa fasilitas tersebut antara lain, laboratorium yang bersertifikat ISO (International Standard Organisation) 17025, fasilitas produksi berstandardisasi CPOB (Cara Pembuatan Obat yang Baik) dan CPOTB (Cara Pembuatan Obat Tradisional yang Baik), pengolahan air demineralisasi dan limbah, klinik holistik, serta lahan agrowisata. Meningkatnya kapasitas produksi yang semakin besar sebab permintaan pasar yang semakin tinggi yakni PT. Industri Jamu dan Farmasi Sido Muncul Tbk telah berhasil memiliki market share terluas dan reputasi yang baik sebagai industri jamu terbesar di Indonesia (Sidomuncul).

Sesuai dengan pasal 74 UU No.40 tahun 2007 tentang perseroan terbatas, pelaksaanaan CSR ditujukan untuk menciptakan hubungan yang harmonis dengan lingkungan, nilai, norma dan budaya masyarakat setempat. Lebih dari itu, PT. Industri Jamu dan Farmasi Sido Muncul Tbk meyakini bahwa kesinambungan usaha selain melalui pencapaian target financial, juga ditunjang investasi non-finansial, seperti yang dilakukan melalui berbagai program CSR. 
Program CSR PT. Industri Jamu dan Farmasi Sido Muncul Tbk diwujudkan dalam bentuk kegiatan sosial yaitu membantu para pedagang jamu dan pedagang asongan dengan program CSR Mudik Lebaran Gratis, Operasi Mata Katarak Tolak Angin, Pemeriksaan Mata Anak Sekolah Dasar, Dana Amal Untuk Berbagi Panti Asuhan, Promo Pariwisata Melalui Iklan Kuku Bima Energi, Program Go Green Sido Muncul.

Mudik Lebaran Gratis adalah salah satu CSR (Corporate Social Responsibility) dari PT. Industri Jamu dan Farmasi Sido Muncul Tbk yang akan menjadi fokus penelitian ini. Mudik Gratis Sido Muncul pertama kali dilaksanakan pada tahun 1991 di lapangan Parkir Timur Senayan dengan 17 bus diikuti oleh 1.200 pedagang jamu. Namun pada tahun 2016 terdapat 16.000 pedagang jamu bisa melakukan perjalanan mudik gratis untuk merayakan Lebaran di kampung halamannya masing-masing. Pemberangkatan mudik gratis ke-27 yang dilakukan Sido Muncul ini menggunakan 270 bus untuk tujuan Cirebon, Kuningan, Tegal, Banjarnegara, Solo, Wonogiri dan Yogyakarta (Hojin, 2016, July 1).

Sebanyak 186 bus, diberangkatkan dari daerah Museum Purna Bhakti Pertiwi, Taman Mini Indonesia Indah (TMII) Jakarta. Sebanyak 84 bus lagi diberangkatkan dari Sukabumi, Bandung, Tangerang, Cilegon, Serang, Cikampek, Bogor, dan Cibinong (Hojin, 2016, July 1).

Tujuan kegiatan ini adalah ingin mewujudkan kebahagiaan bagi para pemudik dan meringankan beban pemerintah dalam mengatasi kesulitan angkutan mudik lebaran (Sidomuncul). Dari uraian terkait diatas mengenai CSR Mudik Lebaran Gratis, penulis ingin meneliti lebih jauh mengenai apakah CSR Mudik Lebaran Gratis memiliki pengaruh terhadap citra perusahaan PT. Industri Jamu dan Farmasi Sido Muncul Tbk. Berdasarkan fenomena tersebut, munculah rumusan masalah yaitu "Hubungan CSR (Corporate Social Resposibility) Mudik Lebaran Gratis 2015 Terhadap Citra Perusahaan PT. Industri Jamu dan Farmasi Sido Muncul Tbk.

\section{TINJAUAN PUSTAKA}

Pada penelitian ini penulis mencoba untuk membahas terdapat hubungan antara Corporate Social Responsibility (CSR) Mudik Lebaran Gratis 2015 terhadap citra perusahaan PT. Industri Jamu dan Farmasi Sido Muncul Tbk. Dengan menggunakan pendekatan kuantitatif yang ingin membuktikan apakah terdapat pengaruh antara CSR terhadap Citra Perusahaan PT. Industri Jamu dan Farmasi Sido Muncul Tbk.

Variabel $\mathrm{X}$ atau variabel independen dalam penelitian ini ialah Corporate Social Responsibility (CSR). Variabel ini dinilai atau diukur melalui tiga dimensi, yakni strengthening economies, protecting the environment, dan understanding. Sementara itu, variabel Y dalam penelitian ini ialah Citra perusahaan PT. Industri Jamu dan Farmasi Sido Muncul Tbk. 
Metode pengumpulan data yang digunakan adalah dengan menggunakan metode survei melalui penyebaran kuesioner. Data yang diperoleh secara langsung (data primer) dari objek yang diteliti, berupa jawaban serta penilaian dari orang-orang yang sudah pernah melihat atau mendengar tetapi belum pernah merasakan dan orang-orang yang sudah pernah merasakan Mudik Lebaran Gratis.

Selain itu, data juga diperoleh dari Studi kepustakaan yang dapat diperoleh dengan membaca buku-buku refrensi, jurnal, internet. Serta, data-data yang diperoleh dari perusahaan yang berhubungan dengan topik penelitian.

Jumlah responden diambil dari orang-orang yang pernah melihat atau merasakan Mudik Lebaran Gratis bersama Sido Muncul, yang berjumlah \pm 20.000 orang. Selanjutnya, Sampel yang diambil harus benar-benar mewakili populasi yang sedang diteliti. Untuk menentukan sampel dari populasi yang diketahui jumlahnya, maka menggunakan rumus slovin. Rumusnya adalah sebagai berikut (Kriyantono, 2012, p.164):

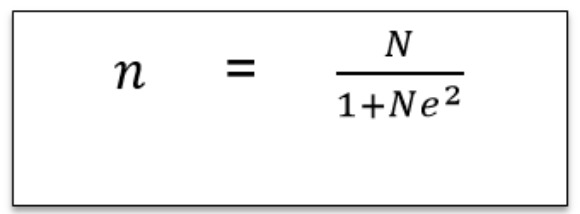

Keterangan :

$n$ = Ukuran Sampel

$\mathrm{N}=$ Ukuran Populasi

e $=$ Kelonggaran ketidaktelitian karena kesalahan pengambilan sampel yang dapat ditolerir, misalnya 2\%, kemudian e ini dikuadratkan. Dari pendekatan atau rumus tersebut, maka dalam penelitian ini digunakan 100 responden terpilih.

Selanjutnya, teknik analisis data yang digunakan oleh penulis ialah dengan menggunakan analisis yang menggunakan uji statistic inferensial dengan tujuan untuk melihat derajat hubungan di antara dua atau lebih dari dua variabel. Kekuatan hubungan yang menunjukkan derajat hubungan ini disebut koefisian asosiasi (kolerasi). Serta, dengan menggunakan atau melihat nilai koefisien korelasi atau derajat kekuatan hubungan dan membuktikan hipotesis hubungan antara variabel/data/skala interval dengan interval lainnya. 


\section{HASIL DAN PEMBAHASAN}

Tabel 1.

Karakteristik Responden Berdasarkan Jenis Kelamin

\begin{tabular}{cccccc}
\hline \multirow{2}{*}{ Valid } & Frequency & Percent & $\begin{array}{c}\text { Valid } \\
\text { Percent }\end{array}$ & $\begin{array}{c}\text { Cumulative } \\
\text { Percent }\end{array}$ \\
\hline \multirow{3}{*}{ Wanita } & 16 & 16,0 & 16,0 & 16,0 \\
\cline { 2 - 6 } & Pria & 84 & 84,0 & 84,0 & 100,0 \\
\cline { 2 - 6 } & Total & 100 & 100,0 & 100,0 & \\
\hline
\end{tabular}

Sumber: Hasil Data Primer, 2017.

Berdasarkan tabel 1 dapat diketahui bahwa dari 100 orang responden yang diteliti, 16 orang $(16,0 \%)$ diantaranya adalah wanita dan 84 orang $(84,0 \%)$ diantaranya adalah pria. Hal ini menunjukan bahwa sebagian besar responden adalah pria.

Tabel 2.

Karakteristik responden Berdasarkan Pendidikan

\begin{tabular}{cccccc}
\hline \multirow{5}{*}{ Valid } & Frequency & Percent & $\begin{array}{c}\text { Valid } \\
\text { Percent }\end{array}$ & $\begin{array}{c}\text { Cumulative } \\
\text { Percent }\end{array}$ \\
\hline \multirow{7}{*}{ S } & SD & 20 & 20,0 & 20,0 & 20,0 \\
\cline { 2 - 6 } & SMK/SMA & 11 & 11,0 & 11,0 & 31,0 \\
\cline { 2 - 6 } & SMP & 69 & 69,0 & 69,0 & 100,0 \\
\cline { 2 - 6 } & Total & 100 & 100,0 & 100,0 & \\
\hline
\end{tabular}

Sumber: Hasil Data Primer, 2017.

Berdasarkan tabel 2 dapat diketahui bahwa dari 100 orang responden yang diteliti, 20 orang $(20,0 \%)$ diantaranya memiliki pendidikan SD, 69 orang $(69,0 \%)$ diantaranya memiliki pendidikan SMP dan 11 orang $(11,0 \%)$ diantaranya memiliki pendidikan SMK/SMA. Hal ini menunjukan bahwa sebagian besar responden memiliki pendidikan SMP.

Tabel 3.

Karakteristik responden Berdasarkan Penghasilan

\begin{tabular}{cccccc}
\hline & Frequency & Percent & $\begin{array}{c}\text { Valid } \\
\text { Percent }\end{array}$ & $\begin{array}{c}\text { Cumulative } \\
\text { Percent }\end{array}$ \\
\hline \multirow{3}{*}{ Valid } & $100.000-300.000$ & 7 & 7,0 & 7,0 & 7,0 \\
\cline { 2 - 6 } & Lebih dari 500.000 & 1 & 1,0 & 1,0 & 8,0 \\
\cline { 2 - 6 } & $300.000-500.000$ & 92 & 92,0 & 92,0 & 100,0 \\
\cline { 2 - 6 } & Total & 100 & 100,0 & 100,0 & \\
\hline
\end{tabular}

Sumber: Hasil Data Primer, 2017. 
Berdasarkan tabel 3 diatas dapat diketahui bahwa dari 100 orang responden yang diteliti, 7 orang $(7,0 \%)$ diantaranya memiliki penghasilan $100.000-300.000,92$ orang $(92,0 \%)$ diantaranya memiliki penghasilan 300.000-500.000 dan 1 orang (1,0\%) diantaranya memiliki penghasilan lebih dari 500.000. Hal ini menunjukan bahwa sebagian besar responden memiliki penghasilan antara 300.000-500.000.

Tabel 4.

Karakteristik responden Berdasarkan Domisili

\begin{tabular}{clcccc}
\hline & Frequency & Percent & $\begin{array}{c}\text { Valid } \\
\text { Percent }\end{array}$ & $\begin{array}{c}\text { Cumulative } \\
\text { Percent }\end{array}$ \\
\hline \multirow{3}{*}{ Valid } & Jakarta Selatan & 3 & 3,0 & 3,0 & 3,0 \\
\cline { 2 - 6 } & Jakarta Barat & 1 & 1,0 & 1,0 & 4,0 \\
\cline { 2 - 6 } & Diluar Jabodetabek & 4 & 4,0 & 4,0 & 8,0 \\
\cline { 2 - 6 } & Jakarta Timur & 92 & 92,0 & 92,0 & 100,0 \\
\cline { 2 - 6 } & Total & 100 & 100,0 & 100,0 & \\
\hline
\end{tabular}

Sumber: Hasil Data Primer, 2017

Selanjutnya, berdasarkan tabel 4 dapat diketahui bahwa dari 100 orang responden yang diteliti, 3 orang $(3,0 \%)$ diantaranya berdomisili Jakarta Selatan, 1 orang $(1,0 \%)$ diantaranya berdomisili Jakarta Barat, 4 orang $(4,0 \%)$ diantaranya berdomisili diluar jabodetabek dan 92 orang $(92,0 \%)$ diantaranya berdomisili Jakarta timur. Hal ini menunjukan bahwa sebagian besar responden berdomisili Jakarta Timur.

Tabel 5.

Karakteristik Responden Berdasarkan Berapa kali Responden Mendapatkan CSR

\begin{tabular}{clcccc}
\hline & Frequency & Percent & $\begin{array}{r}\text { Valid } \\
\text { Percent }\end{array}$ & $\begin{array}{c}\text { Cumulative } \\
\text { Percent }\end{array}$ \\
\hline \multirow{5}{*}{ Valid } & Satu Kali & 17 & 17,0 & 17,0 & 17,0 \\
\cline { 2 - 6 } & Tiga Kali & 7 & 7,0 & 7,0 & 24,0 \\
\cline { 2 - 6 } & Empat Kali atau Lebih & 2 & 2,0 & 2,0 & 26,0 \\
\cline { 2 - 6 } & Dua Kali & 74 & 74,0 & 74,0 & 100,0 \\
\cline { 2 - 6 } & Total & 100 & 100,0 & 100,0 & \\
\hline
\end{tabular}

Sumber: Hasil Data Primer, 2017.

Bila dilihat dari berapa kali responden mendapatkan CSR, maka dapat diketahui bahwa dari 100 orang responden yang diteliti, 17 orang $(17,0 \%)$ diantaranya Mendapatkan CSR satu kali, 74 orang $(74,0 \%)$ diantaranya Mendapatkan CSR dua kali, 7 orang $(7,0 \%)$ diantaranya Mendapatkan CSR tiga kali dan 2 orang (2,0\%) diantaranya Mendapatkan CSR empat kali atau lebih. Hal ini menunjukan bahwa sebagian besar responden Mendapatkan CSR sebanyak 2 kali. 


\section{CSR (Variabel X) \\ Strengthening Economies}

Tabel 6.

(X1) CSR Berkaitan dengan Isu-isu Lingkungan

\begin{tabular}{cccccc}
\hline & Frequency & Percent & $\begin{array}{c}\text { Valid } \\
\text { Percent }\end{array}$ & $\begin{array}{c}\text { Cumulative } \\
\text { Percent }\end{array}$ \\
\hline \multirow{3}{*}{ Valid } & $4-6$ (Biasa Saja) & 5 & 5,0 & 5,0 & 5,0 \\
\cline { 2 - 6 } & $7-9$ (Selalu) & 95 & 95,0 & 95,0 & 100,0 \\
\cline { 2 - 6 } & Total & 100 & 100,0 & 100,0 & \\
\hline
\end{tabular}

Sumber: Hasil Data Primer, 2017.

Berdasarkan tabel 6 di atas dapat diketahui bahwa dari 100 orang responden yang diteliti, 5 orang $(5,0 \%)$ diantaranya menyatakan biasa saja, dan 95 orang $(95,0 \%)$ diantaranya menyatakan selalu. Hal ini menunjukan bahwa sebagian besar responden menilai bahwa CSR selalu Berkaitan dengan Isu-isu Lingkungan. Sesuai yang dikatakan oleh Wahyudi dan Azheri dalam Mardikanto (2014,p.156) bahwa Protecting The Environment salah satu aktivitas CSR yang mengharuskan perusahaan untuk menjaga lingkungan sekitar.

Tabel 7.

(X2) CSR Berkaitan dengan Sosial

\begin{tabular}{cccccc}
\hline & Frequency & Percent & $\begin{array}{r}\text { Valid } \\
\text { Percent }\end{array}$ & $\begin{array}{c}\text { Cumulative } \\
\text { Percent }\end{array}$ \\
\hline \multirow{3}{*}{ Valid } & $4-6($ Tertentu) & 1 & 1,0 & 1,0 & 1,0 \\
\cline { 2 - 6 } & $7-9$ (Sosial) & 99 & 99,0 & 99,0 & 100,0 \\
\cline { 2 - 6 } & Total & 100 & 100,0 & 100,0 & \\
\hline
\end{tabular}

Sumber: Hasil Data Primer, 2017.

Tabel 7 menunjukkan 100 orang responden yang diteliti, 1 orang (1,0\%) diantaranya menyatakan biasa saja, dan 99 orang $(99,0 \%)$ diantaranya menyatakan sosial. Hal ini menunjukan bahwa sebagian besar responden menilai bahwa CSR Berkaitan dengan Sosial.

Tabel 8. (X3)

CSR Meningkatkan Ekonomi

\begin{tabular}{cccccc}
\hline & Frequency & Percent & $\begin{array}{r}\text { Valid } \\
\text { Percent }\end{array}$ & $\begin{array}{c}\text { Cumulative } \\
\text { Percent }\end{array}$ \\
\hline \multirow{3}{*}{ Valid } & $4-6$ (Biasa Saja) & 3 & 3,0 & 3,0 & 3,0 \\
\cline { 2 - 6 } & $7-9$ (Menaikkan) & 97 & 97,0 & 97,0 & 100,0 \\
\cline { 2 - 6 } & Total & 100 & 100,0 & 100,0 & \\
\hline
\end{tabular}

Sumber: Hasil Data Primer, 2017. 
Selanjutnya, tabel 8 merepresentasikan bahwa dari 100 orang responden yang diteliti, 3 orang $(3,0 \%)$ diantaranya menyatakan biasa saja, dan 97 orang $(97,0 \%)$ diantaranya menyatakan menaikan. Hal ini menunjukan bahwa sebagian besar responden menilai bahwa CSR dapat Meningkatkan Ekonomi. Sesuai dengan Wahyudi dan Azhari dalam Mardikanto (2014, p.156) salah satu aktivitas CSR Strengthening Economies yaitu perusahaan harus memberdayakan ekonomi masyarakat sekitarnya, agar terjadi pemerataan kesejahteraan.

\section{Protecting The Environment}

Tabel 9.

(X4) CSR Berkaitan dengan Keinginan Kelestarian Lingkungan

\begin{tabular}{cccccc}
\hline & Frequency & Percent & $\begin{array}{r}\text { Valid } \\
\text { Percent }\end{array}$ & $\begin{array}{c}\text { Cumulative } \\
\text { Percent }\end{array}$ \\
\hline \multirow{3}{*}{ Valid } & $4-6$ (Biasa Saja) & 3 & 3,0 & 3,0 & 3,0 \\
\cline { 2 - 6 } & $7-9$ (Kelestarian) & 97 & 97,0 & 97,0 & 100,0 \\
\cline { 2 - 6 } & Total & 100 & 100,0 & 100,0 & \\
\hline
\end{tabular}

Sumber: Hasil Data Primer, 2017.

Berdasarkan tabel 9 dapat diketahui bahwa dari 100 orang responden yang diteliti, 3 orang $(3,0 \%)$ diantaranya menyatakan biasa saja, dan 97 orang $(97,0 \%)$ diantaranya menyatakan kelestarian. Hal ini menunjukan bahwa sebagian besar responden menilai bahwa CSR Berkaitan dengan Keinginan Kelestarian Lingkungan. Sesuai dengan Asih dalam Mardikanto (2014,p.133), menjalankan tanggung jawab sosial, perusahaan memfokuskan perhatiannya pada 3 hal yaitu keuntungan (profit), masyarakat (people), dan lingkungan (planet). Dengan memperhatikan lingkungan, perusahaan dapat ikut berpartisipasi dalam usaha pelestarian lingkungan demi terpeliharanya kualitas hidup umat manusia dalam jangka panjang. Keterlibatan perusahaan dalam pemeliharaan dan pelestarian lingkungan berarti perusahaan berpartisipasi dalam usaha mencegah terjadinya bencana yang diakibatkan oleh kerusakan lingkungan

Tabel 10.

(X5) CSR Akan Mempererat Lingkungan

\begin{tabular}{cccccc}
\hline & Frequency & Percent & $\begin{array}{r}\text { Valid } \\
\text { Percent }\end{array}$ & $\begin{array}{c}\text { Cumulative } \\
\text { Percent }\end{array}$ \\
\hline \multirow{3}{*}{ Valid } & $4-6$ (Biasa Saja) & 1 & 1,0 & 1,0 & 1,0 \\
\cline { 2 - 6 } & $7-9$ (Mempererat) & 99 & 99,0 & 99,0 & 100,0 \\
\cline { 2 - 6 } & Total & 100 & 100,0 & 100,0 & \\
\hline
\end{tabular}

Sumber: Hasil Data Primer, 2017. 
Dan tabel 10 menunjukkan bahwa 100 orang responden yang diteliti, 1 orang $(1,0 \%)$ diantaranya menyatakan biasa saja, dan 99 orang $(99,0 \%)$ diantaranya menyatakan mempererat. Hal ini menunjukan bahwa sebagian besar responden menilai bahwa CSR Akan Mempererat Lingkungan.

Tabel 11.

(X6) CSR Di khususkan

\begin{tabular}{cccccc}
\hline & Frequency & Percent & $\begin{array}{c}\text { Valid } \\
\text { Percent }\end{array}$ & $\begin{array}{c}\text { Cumulative } \\
\text { Percent }\end{array}$ \\
\hline \multirow{3}{*}{ Valid } & 4-6 (Tertentu) & 1 & 1,0 & 1,0 & 1,0 \\
\cline { 2 - 6 } & 7-9 (Pedagang Jamu) & 99 & 99,0 & 99,0 & 100,0 \\
\cline { 2 - 6 } & Total & 100 & 100,0 & 100,0 & \\
\hline
\end{tabular}

Sumber: Hasil Data Primer, 2017.

Berdasarkan tabel 11 dapat diketahui bahwa dari 100 orang responden yang diteliti, 1 orang $(1,0 \%)$ diantaranya menyatakan tertentu, dan 99 orang $(99,0 \%)$ diantaranya menyatakan pedagang jamu. Hal ini menunjukan bahwa sebagian besar responden menilai bahwa CSR Di khususkan untuk pedagang jamu.

\section{Pemahaman}

Tabel 12.

(X7) CSR Tepat Sasaran

\begin{tabular}{cccccc}
\hline & Frequency & Percent & $\begin{array}{c}\text { Valid } \\
\text { Percent }\end{array}$ & $\begin{array}{c}\text { Cumulative } \\
\text { Percent }\end{array}$ \\
\hline \multirow{3}{*}{ Valid } & $4-6$ (Biasa Saja) & 2 & 2,0 & 2,0 & 2,0 \\
\cline { 2 - 6 } & $7-9$ (Tepat) & 98 & 98,0 & 98,0 & 100,0 \\
\cline { 2 - 6 } & Total & 100 & 100,0 & 100,0 & \\
\hline
\end{tabular}

Sumber: Hasil Data Primer, 2017.

Berdasarkan tabel 12 dapat diketahui bahwa dari 100 orang responden yang diteliti, 2 orang $(2,0 \%)$ diantaranya menyatakan basa saja, dan 98 orang $(98,0 \%)$ diantaranya menyatakan tepat. Hal ini menunjukan bahwa sebagian besar responden menilai bahwa CSR sudah tepat sasaran.

Tabel 13.

(X8) Peserta CSR Pihak yang Tepat

\begin{tabular}{cccccc}
\hline & & Frequency & Percent & $\begin{array}{c}\text { Valid } \\
\text { Percent }\end{array}$ & $\begin{array}{c}\text { Cumulative } \\
\text { Percent }\end{array}$ \\
\hline \multirow{3}{*}{ Valid } & 4-6 (Biasa Saja) & 2 & 2,0 & 2,0 & 2,0 \\
\cline { 2 - 6 } & 7-9 (Tepat) & 98 & 98,0 & 98,0 & 100,0 \\
\cline { 2 - 6 } & Total & 100 & 100,0 & 100,0 & \\
\hline
\end{tabular}

Sumber: Hasil Data Primer, 2017. 
Tabel 13 menunjukkan bahwa dari 100 orang responden yang diteliti, 2 orang (2,0\%) diantaranya menyatakan biasa saja, dan 98 orang $(98,0 \%)$ diantaranya menyatakan tepat. Hal ini menunjukan bahwa sebagian besar responden menilai bahwa Peserta CSR Pihak yang Tepat.

Tabel 14.

(X9) CSR Di jalankan dengan Tulus

\begin{tabular}{cccccc}
\hline \multirow{2}{*}{ Valid } & Frequency & Percent & $\begin{array}{c}\text { Valid } \\
\text { Percent }\end{array}$ & $\begin{array}{c}\text { Cumulative } \\
\text { Percent }\end{array}$ \\
\hline \multirow{3}{*}{ 4-6 (Biasa Saja) } & 1 & 1,0 & 1,0 & 1,0 \\
\cline { 2 - 6 } & 7-9 (Tulus) & 99 & 99,0 & 99,0 & 100,0 \\
\cline { 2 - 6 } & Total & 100 & 100,0 & 100,0 & \\
\hline
\end{tabular}

Sumber: Hasil Data Primer, 2017.

Terakhir, tabel 14 merepresentasikan 100 orang responden yang diteliti, semuanya menyatakan CSR Di jalankan dengan Tulus.

\section{Citra Perusahaan (Variabel Y)}

Dynamic

Tabel 15.

(Y1) CSR Mudik Lebaran Gratis Program Pertama

\begin{tabular}{cccccc}
\hline & & Frequency & Percent & $\begin{array}{c}\text { Valid } \\
\text { Percent }\end{array}$ & $\begin{array}{c}\text { Cumulative } \\
\text { Percent }\end{array}$ \\
\hline \multirow{3}{*}{ Valid } & 4-6 (Biasa Saja) & 3 & 3,0 & 3,0 & 3,0 \\
\cline { 2 - 6 } & $7-9$ (Pelopor) & 97 & 97,0 & 97,0 & 100,0 \\
\cline { 2 - 6 } & Total & 100 & 100,0 & 100,0 & \\
\hline
\end{tabular}

Sumber: Hasil Data Primer, 2017

Berdasarkan tabel 15 dapat diketahui bahwa dari 100 orang responden yang diteliti, 3 orang $(3,0 \%)$ diantaranya menyatakan biasa saja, dan 97 orang $(97,0 \%)$ diantaranya menyatakan pelopor. Hal ini menunjukan bahwa sebagian besar responden menilai bahwa CSR Mudik Lebaran Gratis Program Pertama.

Tabel 16.

(Y2) CSR Menarik Perhatian Responden

\begin{tabular}{cccccc}
\hline \multirow{3}{*}{ Valid } & Frequency & Percent & $\begin{array}{c}\text { Valid } \\
\text { Percent }\end{array}$ & $\begin{array}{c}\text { Cumulative } \\
\text { Percent }\end{array}$ \\
\hline \multirow{3}{*}{$\begin{array}{c}4-6 \text { (Biasa Saja) } \\
\text { 7-9 (Menarik } \\
\text { Perhatian) }\end{array}$} & 2 & 2,0 & 2,0 & 2,0 \\
\cline { 2 - 6 } & Total & 100 & 98,0 & 98,0 & 100,0 \\
\hline
\end{tabular}

Sumber: Hasil Data Primer, 2017 
Berdasarkan tabel 16 dapat diketahui bahwa dari 100 orang responden yang diteliti, 2 orang $(2,0 \%)$ diantaranya menyatakan biasa saja, dan 98 orang $(98,0 \%)$ diantaranya menyatakan menarik perhatian. Hal ini menunjukan bahwa sebagian besar responden menilai bahwa CSR Menarik Perhatian Responden.

Tabel 17.

(Y3) Keaktifan Sido Muncul dalam Menjalankan CSR

\begin{tabular}{cccccc}
\hline & & Frequency & Percent & $\begin{array}{c}\text { Valid } \\
\text { Percent }\end{array}$ & $\begin{array}{c}\text { Cumulative } \\
\text { Percent }\end{array}$ \\
\hline \multirow{3}{*}{ Valid } & 4-6 (Biasa Saja) & 1 & 1,0 & 1,0 & 1,0 \\
\cline { 2 - 6 } & $7-9$ (Aktif) & 99 & 99,0 & 99,0 & 100,0 \\
\cline { 2 - 6 } & Total & 100 & 100,0 & 100,0 & \\
\hline
\end{tabular}

Sumber: Hasil Data Primer, 2017.

Mengacu pada tabel 15 dapat diketahui bahwa dari 100 orang responden yang diteliti, 1 orang $(1,0 \%)$ diantaranya menyatakan biasa saja, dan 99 orang $(99,0 \%)$ diantaranya menyatakan aktif. Hal ini menunjukan bahwa sebagian besar responden menilai bahwa Keaktifan Sido Muncul dalam Menjalankan CSR. Sesuai yang dikatakan Fill dalam Yunatan (2016,p5) bahwa sebuah organisasi atau perusahaan haruslah dinamis: pelopor, menarik perhatian, aktif dan berorientasi pada tujuan.

\section{Cooperative}

Tabel 18.

(Y4) CSR Berkesinambungan

\begin{tabular}{cccccc}
\hline & & Frequency & Percent & $\begin{array}{c}\text { Valid } \\
\text { Percent }\end{array}$ & $\begin{array}{c}\text { Cumulative } \\
\text { Percent }\end{array}$ \\
\hline \multirow{3}{*}{ Valid } & $4-6$ (Biasa Saja) & 3 & 3,0 & 3,0 & 3,0 \\
\cline { 2 - 6 } & $\begin{array}{c}7-9 \\
\text { (Berkesinambungan) }\end{array}$ & 97 & 97,0 & 97,0 & 100,0 \\
\cline { 2 - 6 } & Total & 100 & 100,0 & 100,0 & \\
\hline
\end{tabular}

Sumber: Hasil Data Primer, 2017.

Berdasarkan tabel 16 dapat diketahui bahwa dari 100 orang responden yang diteliti, 3 orang $(3,0 \%)$ diantaranya menyatakan biasa saja, dan 97 orang $(97,0 \%)$ diantaranya menyatakan berkesinambungan. Hal ini menunjukan bahwa sebagian besar responden menilai bahwa CSR Berkesinambungan. Sesuai yang dikatakan Wahyudi dan Azheri dalam Mardikanti (2014, p.156), Continuity and Sustainability atau berkesinambungan dan berkelanjutan merupakan unsur vital dari CSR. Suatu kegiatan amal yang berdasar trend ataupun isidental bukanlah CSR. CSR adalah suatu kegiatan yang terencanakan, sistematis, dan dapat di evaluasi. 
Tabel 19.

(Y5) Sido Muncul Memperlakukan Masyarakat dengan Ramah

\begin{tabular}{cccccc}
\hline & & Frequency & Percent & $\begin{array}{r}\text { Valid } \\
\text { Percent }\end{array}$ & $\begin{array}{c}\text { Cumulative } \\
\text { Percent }\end{array}$ \\
\hline \multirow{3}{*}{ Valid } & $4-6$ (Biasa Saja) & 3 & 3,0 & 3,0 & 3,0 \\
\cline { 2 - 6 } & $7-9$ (Ramah) & 97 & 97,0 & 97,0 & 100,0 \\
\cline { 2 - 6 } & Total & 100 & 100,0 & 100,0 & \\
\hline
\end{tabular}

Sumber: Hasil Data Primer, 2017.

Selanjutnya tabel 19 menunjukkan bahwa 100 orang responden yang diteliti, 3 orang $(3,0 \%)$ diantaranya menyatakan biasa saja, dan 97 orang $(97,0 \%)$ diantaranya menyatakan ramah. Hal ini menunjukan bahwa sebagian besar responden menilai bahwa Sido Muncul Memperlakukan Masyarakat dengan Ramah. Hal ini menegaskan pernyataan Wahyudi dan Azhheri dalam Mardikanto (2014, p.156) salah satu aktifitas CSR Assessing Social Cohesion yaitu upaya menjaga keharmonisan dengan masyarakat sekitar, agar tidak menimbulkan konflik.

Tabel 20.

(Y6) Setelah adanya CSR, Apakah Sido Muncul akan disukai oleh Responden

\begin{tabular}{cccccc}
\hline & & Frequency & Percent & $\begin{array}{r}\text { Valid } \\
\text { Percent }\end{array}$ & $\begin{array}{c}\text { Cumulative } \\
\text { Percent }\end{array}$ \\
\hline \multirow{3}{*}{ Valid } & $4-6$ (Biasa Saja) & 1 & 1,0 & 1,0 & 1,0 \\
\cline { 2 - 6 } & $7-9$ (Disukai) & 99 & 99,0 & 99,0 & 100,0 \\
\cline { 2 - 6 } & Total & 100 & 100,0 & 100,0 & \\
\hline
\end{tabular}

Sumber: Hasil Data Primer, 2017.

Berdasarkan tabel 20 menunjukkan 100 orang responden yang diteliti, semuanya menyatakan Setelah adanya CSR, Sido Muncul akan disukai oleh Responden.

\section{Character}

Tabel 21.

(Y7) CSR Layak Dilakukan

\begin{tabular}{llllll}
\hline & & Frequency & Percent & $\begin{array}{r}\text { Valid } \\
\text { Percent }\end{array}$ & $\begin{array}{c}\text { Cumulative } \\
\text { Percent }\end{array}$ \\
\hline \multirow{3}{*}{ Valid } & 4-6 (Biasa Saja) & 1 & 1,0 & 1,0 & 1,0 \\
\cline { 2 - 6 } & 7-9 (Layak) & 99 & 99,0 & 99,0 & 100,0 \\
\cline { 2 - 6 } & Total & 100 & 100,0 & 100,0 & \\
\hline
\end{tabular}

Sumber: Hasil Data Primer, 2017.

Berdasarkan tabel 21 menunjukkan bahwa dapat diketahui bahwa dari 100 orang responden yang diteliti, semuanya menyatakan CSR Layak Dilakukan. 
Tabel 22.

(Y8) CSR Mudik Lebaran Gratis Membuat Pemudik Menyepelekkan

\begin{tabular}{cccccc}
\hline & & Frequency & Percent & $\begin{array}{c}\text { Valid } \\
\text { Percent }\end{array}$ & $\begin{array}{c}\text { Cumulative } \\
\text { Percent }\end{array}$ \\
\hline \multirow{3}{*}{ Valid } & $4-6$ (Biasa Saja) & 4 & 4,0 & 4,0 & 4,0 \\
\cline { 2 - 6 } & $7-9$ (Serius) & 96 & 96,0 & 96,0 & 100,0 \\
\cline { 2 - 6 } & Total & 100 & 100,0 & 100,0 & \\
\hline
\end{tabular}

Sumber: Hasil Data Primer, 2017.

Berdasarkan tabel 22 dapat diketahui bahwa dari 100 orang responden yang diteliti, 4 orang $(4,0 \%)$ diantaranya menyatakan biasa saja, dan 96 orang $(96,0 \%)$ diantaranya menyatakan serius. Hal ini menunjukan bahwa sebagian besar responden menilai pemudik serius dalam program CSR Mudik Lebaran Gratis.

\section{Uji Validitas \& Reliabilitas}

Terdapat 30 orang yang dijadikan responden dalam penelitian ini untuk menjawab 22 pertanyaan yang terdapat dalam kuesioner. Dalam penyebaran instrument penelitian, hasil penelitian akan dikatakan valid jika terdapat kesamaan antara datayang terkumpul dengan data yang sesungguhnya terjadi pada objek penelitian.

Tabel 23.

Pengujian Validitas Variabel CSR (X)

\begin{tabular}{l|c|c|c|c}
\hline \multicolumn{4}{c}{ Item-Total Statistics } \\
\hline & $\begin{array}{c}\text { Scale Mean if } \\
\text { Item Deleted }\end{array}$ & $\begin{array}{c}\text { Scale } \\
\text { Variance if } \\
\text { Item Deleted }\end{array}$ & $\begin{array}{c}\text { Corrected } \\
\text { Item-Total } \\
\text { Correlation }\end{array}$ & $\begin{array}{c}\text { Cronbach's } \\
\text { Alpha if } \\
\text { Item } \\
\text { Deleted }\end{array}$ \\
\hline $\begin{array}{l}\text { CSR Berkaitan dengan } \\
\text { Isu-isu Lingkungan? }\end{array}$ & 23,60 & 2,248 &, 588 &, 945 \\
\hline $\begin{array}{l}\text { CSR Berkaitan dengan } \\
\text { Sosial? }\end{array}$ & 23,53 & 2,326 &, 933 &, 923 \\
\hline $\begin{array}{l}\text { CSR Meningkatkan } \\
\text { Ekonomi? }\end{array}$ & 23,60 & 2,248 &, 588 &, 945 \\
\hline $\begin{array}{l}\text { CSR Berkaitan dengan } \\
\text { Keinginan Kelestarian }\end{array}$ & 23,57 & 2,254 &, 736 &, 931 \\
Lingkungan? & 23,53 & 2,326 &, 933 &, 923 \\
\hline $\begin{array}{l}\text { CSR Akan } \\
\text { Mempererat }\end{array}$ & & & & \\
\hline
\end{tabular}




\begin{tabular}{l|c|c|c|c}
\hline \multicolumn{5}{c}{ Item-Total Statistics } \\
\hline & $\begin{array}{l}\text { Scale Mean if } \\
\text { Item Deleted }\end{array}$ & $\begin{array}{c}\text { Scale } \\
\text { Variance if } \\
\text { Item Deleted }\end{array}$ & $\begin{array}{c}\text { Corrected } \\
\text { Item-Total } \\
\text { Correlation }\end{array}$ & $\begin{array}{c}\text { Cronbach's } \\
\text { Alpha if } \\
\text { Item } \\
\text { Deleted }\end{array}$ \\
\hline $\begin{array}{l}\text { CSR Di khususkan } \\
\text { untuk? }\end{array}$ & 23,53 & 2,326 &, 933 &, 923 \\
\hline $\begin{array}{l}\text { CSR Tepat Sasaran? } \\
\begin{array}{l}\text { Peserta CSR Pihak } \\
\text { yang Tepat? }\end{array}\end{array} \quad 23,53$ & 2,326 &, 933 &, 923 \\
\hline $\begin{array}{l}\text { CSR Di jalankan } \\
\text { dengan Tulus? }\end{array}$ & 23,57 & 2,254 &, 736 &, 931 \\
\hline
\end{tabular}

Sumber: Data Primer, 2017.

Menurut Sugiyono (2015, p.121), Intrumen yang valid berarti alat ukur yang digunakan untuk mendapatkan data mengukur itu valid. Valid adalah instrument dapat digunakan untuk mengukur apa yang seharusnya diukur.

Berdasarkan tabel 21 dapat diketahui bahwa semua item pernyataan memiliki nilai corrected Item-Total correlation lebih besar dari $r$ tabel 0,361. Sehingga dapat disimpulkan bahwa semua item pernyataan valid dalam mengukur variabel CSR (X).

Tabel 24.

Pengujian Validitas Variabel Citra Perusahaan (Y)

\begin{tabular}{l|c|c|c|c}
\hline \multicolumn{5}{|c}{ Item-Total Statistics } \\
\hline & $\begin{array}{c}\text { Scale Mean if } \\
\text { Item Deleted }\end{array}$ & $\begin{array}{c}\text { Scale Variance } \\
\text { if Item } \\
\text { Deleted }\end{array}$ & $\begin{array}{c}\text { Corrected } \\
\text { Item-Total } \\
\text { Correlation }\end{array}$ & $\begin{array}{c}\text { Cronbach's } \\
\text { Alpha if Item } \\
\text { Deleted }\end{array}$ \\
\hline $\begin{array}{l}\text { CSR Mudik Lebaran } \\
\text { Gratis Program } \\
\text { Pertama? }\end{array}$ & 20,53 & 1,982 &, 779 &, 905 \\
\hline $\begin{array}{l}\text { CSR Menarik Perhatian } \\
\text { Responden? }\end{array}$ & 20,53 & 1,982 &, 779 &, 905 \\
\hline $\begin{array}{l}\text { Keaktifan Sido Muncul } \\
\text { dalam Menjalankan CSR }\end{array}$ & 20,50 & 2,121 &, 843 &, 906 \\
\hline
\end{tabular}




\begin{tabular}{|c|c|c|c|c|}
\hline \multicolumn{5}{|c|}{ Item-Total Statistics } \\
\hline & $\begin{array}{l}\text { Scale Mean if } \\
\text { Item Deleted }\end{array}$ & $\begin{array}{c}\text { Scale Variance } \\
\text { if Item } \\
\text { Deleted }\end{array}$ & $\begin{array}{c}\text { Corrected } \\
\text { Item-Total } \\
\text { Correlation }\end{array}$ & $\begin{array}{c}\text { Cronbach's } \\
\text { Alpha if Item } \\
\text { Deleted }\end{array}$ \\
\hline CSR Berkesinambungan? & 20,57 & 1,978 & 619 & ,922 \\
\hline $\begin{array}{l}\text { Sido Muncul } \\
\text { Memperlakukan } \\
\text { Masyarakat dengan } \\
\text { Ramah? }\end{array}$ & 20,57 & 1,840 & ,808 & ,904 \\
\hline $\begin{array}{l}\text { Setelah adanya CSR, } \\
\text { Apakah Sido Muncul } \\
\text { akan disukai oleh } \\
\text { Responden? }\end{array}$ & 20,50 & 2,121 & ,843 & ,906 \\
\hline CSR Layak Dilakukan? & 20,50 & 2,121 & 843 & ,906 \\
\hline $\begin{array}{l}\text { CSR Mudik Lebaran } \\
\text { Gratis Membuat } \\
\text { Pemudik } \\
\text { Menyepelekkan? }\end{array}$ & 20,57 & 1,978 & 619 & ,922 \\
\hline
\end{tabular}

Sumber: Data Primer, 2017.

Berdasarkan tabel 24 dapat diketahui bahwa semua item pernyataan memiliki nilai corrected Item-Total correlation lebih besar dari $r$ tabel 0,361. Sehingga dapat disimpulkan bahwa semua item pernyataan valid dalam mengukur variabel Citra Perusahaan (Y).

Setelah dilakukan tahap uji validitas pada variable X dan variable $\mathrm{Y}$, dilanjutkan dengan analisis pengujian reliabilitas data. Tujuan pengujian reliabilitas ini adalah untuk mengukur konsistensi responden dalam memberikan penilaian atas apa yang diukur melalui pernyataan-pernyataan dalam kuesioner.

Tabel 25.

Uji Reliabilitas Variabel CSR (X)

\begin{tabular}{|c|c|}
\hline \multicolumn{2}{|c|}{ Reliability Statistics } \\
\hline Cronbach's Alpha & N of Items \\
\hline, 937 & 9 \\
\hline
\end{tabular}

Sumber: Data Primer, 2017. 
Berdasarkan hasil pengujian pada tabel 25 dapat diketahui bahwa nilai cronbach alpha variabel CSR sebesar 0,937 > 0,7. Sehingga dapat disimpulkan bahwa semua item memiliki kekonsistenan dalam mengukur variabel CSR (X).

Tabel 26.

Uji Reliabilitas Variabel Citra Perusahan (Y)

\begin{tabular}{|c|c|}
\hline \multicolumn{2}{|c|}{ Reliability Statistics } \\
\hline Cronbach's Alpha & N of Items \\
\hline, 920 & 8 \\
\hline
\end{tabular}

Sumber: Data Primer, 2017.

Berdasarkan hasil pengujian pada tabel 26 dapat diketahui bahwa nilai cronbach alpha variabel Citra Perusahaan (Y) sebesar 0,920 > 0,7. Sehingga dapat disimpulkan bahwa semua item memiliki kekonsistenan dalam mengukur variabel Citra Perusahaan (Y).

\section{Uji Hipotesis}

Tabel 27.

Uji Korelasi

\begin{tabular}{|c|c|c|c|}
\hline & & CSR $(\mathrm{X})$ & Citra Perusahaan (Y) \\
\hline \multirow{3}{*}{ CSR $(\mathrm{X})$} & Pearson Correlation & 1 & .075 \\
\cline { 2 - 4 } & Sig. (2-tailed) & & .459 \\
\cline { 2 - 4 } & $\mathrm{N}$ & 100 & 100 \\
\hline \multirow{3}{*}{ Citra Perusahaan (Y) } & Pearson Correlation & .075 & 1 \\
\cline { 2 - 4 } & Sig. (2-tailed) & .459 & 100 \\
\cline { 2 - 4 } & $\mathrm{N}$ & 100 & 100 \\
\hline
\end{tabular}

Sumber: Data Olahan Peneliti, 2017.

Dari tabel diatas dapat diketahui bahwa besarnya hubungan antara CSR Dengan Citra perusahaan adalah 0,075. Hubungan ini termasuk dalam kategori sangat lemah. Korelasi tersebut memiliki arah hubungan positif artinya, semakin tinggi CSR maka akan meningkatkan Citra Perusahaan. Berdasarkan hasil uji korelasi tersebut diperoleh nilai sig sebesar 0,459 > 0,05 maka tidak signifikan. Sehingga dapat disimpulkan bahwa tidak terdapat hubungan yang signifikan antara CSR Dengan Citra perusahaan.

\section{Pembahasan}

Dari hasil analisis uji korelasi diatas dapat diketahui bahwa tidak terdapat hubungan yang signifikan antara CSR (Corporate Social Responsibility) Mudik Lebaran Gratis terhadap citra PT. Industri Jamu dan Farmasi Sido Muncul Tbk. Dengan perolehan R square sebesar 0,075 yang berarti sangat lemah sekali hubungan diantara kedua variabel tersebut. (masukin teori yang sesuai dengan ini, seharusnya Perusahaan jamu mengadakan kegiatan CSR yang sesuai dengan core business seperti kesadaran 
masyarakat terhadap kesehatan. Seperti contohnya kegiatan penyuluhan kesehatan kepada masyarakat sekitar pabrik, kesadaran akan pengenalan dunia medis kepada masyarakat luas.

Dilihat dari penyebaran skor rata-rata (mean) masing-masing dimensi pada variabel CSR, dapat diketahui bahwa dimensi Protecting The Environment dan Pemahaman memiliki penilaian yang sama dengan peroleh skor rata-rata masing-masing dimensi sebesar 2,983 dan dimensi Strengthening Economies memperoleh skor rata-rata sebesar 2,97. Hal ini menunjukan bahwa penilaian responden terhadap dimensi Protecting The Environment dan Pemahaman lebih tinggi dibandingkan dengan dimensi Strengthening Economies.

Chakraborty 2010 (dalam Mardikanto, 2014,p.132) Corporate Social Responsibility (CSR) adalah tentang bagaimana perusahaan mengelola proses bisnis untuk menghasilkan dampak positif secara keseluruhan pada masyarakat.

Perusahaan jamu PT. Industri Jamu dan Farmasi Sido Muncul Tbk mengelola proses bisnis yang memberikan dampak positif bagi masyarakat melewati program CSR Mudik Lebaran Gratis yang dibuat oleh PT. Industri Jamu dan Farmasi Sido Muncul Tbk kepada penjual jamu dan pedagang asongan untuk membantu transportasi mereka yang ingin pulang kekampung halamannya.

Sedangkan menurut Tanaya 2004 (dalam Mardikanto, 2014,p. 133) bahwa, esensi CSR merupakan wujud dari giving back dari perusahaan kepada komunitas atau masyarakat sekitar, yang dapat dilakukan untuk menghasilkan bisnis berdasarkan niat tulus guna member kontribusi yang paling positif pada masyarakat sekitar (stakeholders).

Jika diilihat dari penyebaran skor rata-rata (mean) masing-masing dimensi pada variabel Citra perusahaan, dapat diketahui bahwa dimensi Cooperative memiliki penilaian yang paling tinggi dengan peroleh skor rata-rata sebesar 2,98, kemudian dimensi Dynamic memperoleh skor rata-rata sebesar 2,9775 dan dimensi Character memperoleh skor rata-rata sebesar 2,975. Hal ini menunjukan bahwa penilaian responden mengenai dimensi Cooperative lebih tinggi dibandingkan kedua dimensi lainnya. Dan penilaian terendah terdapat pada dimensi Character. Menurut Fill dalam Yunatan (2016,p.5) bahwa Cooperative: friendly, well-liked, eager to please good relations sebuah organisasi harus mampu bekerja sama: ramah, disukai, membuat senang orang lain dan memiliki hubungan baik dengan orang lain. 


\section{SIMPULAN}

Berdasarkan hasil penelitian yang telah dilakukan dapat disimpulkan bahwa tidak terdapat hubungan yang signifikan antara CSR Mudik Lebaran Gratis oleh PT Industri Jamu dan Farmasi Sido Muncul Tbk dengan citra perusahaan. Diketahui nilai koefisien korelasi hanya sebesar 0,075 yang masuk dalam kategori sangat lemah. Kegiatan CSR mudik lebaran gratis oleh PT Sidomuncul dipandang sangat baik oleh masyarakat yang dalam hal ini diwakili oleh pedagang jamu. Bila dilihat faktor yang paling dilihat pada kegiatan CSR adalah Protecting The Environment yang mengharuskan perusahaan untuk menjaga lingkungan sekitar. dan Pemahaman yaitu proses seseorang membentuk berbagai arti dan struktur pengetahuan yang mewakili konsep, objek, perilaku dan peristiwa relevan dalam hidup seseorang atau individu tersebut. Protecting the Environment dan Pemahaman memiliki penilaian yang sama (mean) 2,983. Sedangkan faktor yang lemah adalah Strengthening Economies (mean) 2,97. Citra perusahaan PT Industri jamu dan farmasi sido muncul, dipandang sangat baik dimata masyarakat yang dalam hal ini adalah pedagang jamu (mean) 2,97. Sedangkan faktor yang paling dilihat dalam citra perusahaan adalah Cooperative (mean) 2,98 yang berarti ramah dan disukai, Sedangkan yang paling rendah dilihat dalam citra perusahaan jamu adalah Character (mean) 2,975.

\section{DAFTAR PUSTAKA}

Azwar, S. (2016). Realibitas dan Validitas.Yogyakarta: Pustaka Pelajar.

Bank Indonesia. [n.d.]. Pola Pembiyaaan Usaha Kecil (PPUK): Industri Jamu

Tradisional (Pola Pembiayaan Syariah). Diperoleh dari website: http://www.bi.go.id/id/umkm/kelayakan/polapembiayaan/industri/Documents/6e6cbc417f0b47beb987c3573e9d646dIndustr iJamuTradisionalSyariah1.pdf

Bungin, B. (2010). Metodologi Penelitian Kuantitatif. Jakarta: Kencana

Chanafi, A., Fauzi, A., \& Sunarti. (2015). Administrasi. Pengaruh Persepsi Masyarakat Terhadap Implementasi Corporate Sosial Responsibility (CSR) dan Dampaknya Pada Citra Perusahaan: Survei Pada Masyarakat Sekitar PT. Greenfields Indonesia Yang Bertempat Tinggal di RW 02 Dusun Maduarjo Desa Babadan Kecamatan Ngajum Kabupaten Malang, 3(1), 1-7. Diperoleh dari http://studentjournal.petra.ac.id/index.php/ilmukomunikasi/article/view/4889/4497.

Effendy,O. (2006). Hubungan Masyarakat. Bandung: PT. Remaja Rosdakarya. 
Gassing, S. S. dan Suryanto. S. (2016). Public Relations. Yogyakarta: C.V Andi.

Hojin. [n.d]. "Ribuan Pedagang Jamu Ikut Mudik Gratis". Diperoleh dari website Sindo News: $\quad$ https://nasional.sindonews.com/read/1121195/15/ribuan-pedagangjamu-ikut-mudik-gratis-1467359600.

Iriantara, Y. (2007). Community Relations Konsep dan Aplikasinya. $\quad$ Bandung: Simbiosa Rekatama Media.

Kriyantono, R. (2015). Public Relations, Issue \& Crisis Management:Pendekatan Critical Public Relations, Etnografi Kritis \& Kualitatif. Jakarta: Prenadamedia Group.

Kriyantono, R. (2012). Teknis Praktis Riset Komunikasi. Jakarta: Kencana.

Liliweri, A. (2014). Sosiologi dan Komunikasi Organisasi. Jakarta: PT Bumi Aksara.

Mardikanto, T. (2014). CSR Corporate Social Responsibility (Tanggung Jawab Sosial Korporasi). Bandung: Alfabeta.

Nasrullah, A. (2015). Studia Islamika. Pengelolaan Dana Filantropi Untuk Pemberdayaan Pendidikan Anak Dhuaf: Studi Kasus pada BMH Cabang Malang Jawa Timur. 12(1), 1-18. Diperoleh dari:http://oaji.net/articles/2015/1163-1434805933.pdf.

Putra, D. (2015). Komunikasi CSR Politik: Membangun Reputasi, Etika, dan Estetika PR Politik. Jakarta: Prenadamedia Group.

Ruslan, R. (2016). Manajemen Public Relations \& Media Komunikasi. Jakarta: PT Raja Grafindo Persada. Sido Muncul. [n.d]. CSR Besarkan Sido Muncul. Diperoleh dari website: www.sidomuncul.com Sido Muncul. [n.d]. Diperoleh dari website:http://www.sidomunculstore.com/sido-muncul.html/.

Solihin, I. (2009). Corporate Social Responsibility from Charity to Sustainability. Jakarta: Salemba Empat.

Sugiyono. (2015). Metode Penelitian Kuantitatif Kualitatif dan R\&D. Bandung: Alfabeta.

Supardi. (2016). Aplikasi Statistika Dalam Penelitian. Jakarta: Ufuk Press.

Winasis, E. G. (2015). 40 Resep Dahsyat Jamu: Penakluk ASAM URAT dan DIABETES. Yogyakarta: Araska.

Widyawati. (2011). Filantropi Islam dan Kebijakan Negara Pasca Orde Baru.

Yunatan, N. C. (2016). Komunikasi. Pengaruh Corporate Social Responsibility“Alfamart Class" di SMK PGRI 3 Malang Terhadap Citra Perusahaan Alfamart, 4(1), 2-11. Diperoleh dari: $\quad$ http://studentjournal.petra.ac.id/index.php/ilmukomunikasi/article/view/4889/4497 